\title{
PAPAYA SEEDLINGS GROWTH USING A LOW-COST, AUTOMATIC WATERING CONTROLLER ${ }^{1}$
}

\author{
GUSTAVO CARDOSO DE OLIVEIRA DIAS ${ }^{2}$, LEONARDO OLIVEIRA MEDICI ${ }^{3}$, \\ MARCO ANTONIO DA SILVA VASCONCELLOS ${ }^{4}$, DANIEL FONSECA DE CARVALHO ${ }^{5}$, \\ CARLOS PIMENTEL ${ }^{6}$
}

\begin{abstract}
The study assessed growth and physiological parameters of 'Sunrise Golden' and 'Tainung 01 ' papaya seedlings grown in $280 \mathrm{~mL}$ plastic tubes and watered using a low-cost automatic irrigation system adjusted to operate at substrate water tension for starting irrigation (STI) of 3.0, 6.0 or $9.0 \mathrm{kPa}$. The water depths applied by the dripping system and drainage were monitored during germination and seedling growth. Germination, emergence velocity index (EVI), leaf area, plant height, shoot and root dry weight, stomatal conductance, relative water content (RWC) and relative chlorophyll content (RCC) were evaluated. Soil nutrient levels were determined by electrical conductivity (EC). Water use efficiency (WUE) corresponded to the ratio of plant dry mass to depth of water applied. STI settings did not affect papaya germination or EVI. System configuration to 3.0 and $6.0 \mathrm{kPa}$ STI exhibited the highest drainage and lowest EC and RCC, indicating soil nutrient loss and plant nutrient deficiency. Drainage was greater in tubes planted with the 'Tainung 01' variety, which developed smaller root systems and lower stomatal conductance than 'Sunrise Golden' seedlings. The highest values for shoot dry weight and WEU were obtained at $6.0 \mathrm{kPa}$ STI for 'Sunrise Golden' $\left(0.62 \mathrm{~g}\right.$ and $\left.0.69 \mathrm{~g} \mathrm{~L}^{-1}\right)$ and at $9.0 \mathrm{kPa}$ in 'Tainung 01 ' $(0.35 \mathrm{~g}$ and $\left.0.82 \mathrm{~g} \mathrm{~L}^{-1}\right)$. RWC at $9.0 \mathrm{kPa}$ STI was lower than at $3.0 \mathrm{kPa}$ in both varieties. The results indicate that the low-cost technology developed for irrigation automation is promising. Even so, new studies are needed to evaluate low-flow irrigation systems as well as the nutrient and water needs of different papaya varieties. Index terms: Carica papaya L., seedling production, irrigation automation, moisture sensors.
\end{abstract}

\section{CRESCIMENTO DE MUDAS DE MAMOEIRO IRRIGADAS AUTOMATICAMENTE COM CONTROLADOR DE BAIXO CUSTO}

RESUMO- O estudo avaliou o crescimento e a fisiologia de mudas de mamoeiros 'Sunrise Golden' e
'Tainung 01' cultivadas em tubetes de $280 \mathrm{~mL}$ e irrigadas com sistema de controle automático de baixo
custo, ajustado para iniciar a irrigação com tensão de água no substrato (STI) a 3,$0 ; 6,0$ e $9,0 \mathrm{kPa}$. As
lâminas aplicadas pelo sistema de gotejamento e as drenagens em cada tratamento foram monitoradas nas
fases de germinação e de crescimento das mudas. Foram analisados: porcentagem de germinação, índice
de velocidade de emergência (EVI), área foliar, altura de planta, massa de matéria seca da parte aérea e
das raízes, condutância estomática, conteúdo relativo de água (RWC) e teor relativo de clorofila (RCC). Os
teores de nutrientes do substrato foram estimados pela condutividade elétrica (EC). A eficiência de uso da
água (WUE) foi calculada como a razão entre a massa seca da planta inteira e a água aplicada. Os valores
testados para a STI não afetaram a porcentagem de germinação e o EVI. As regulagens de 3,0 e de 6,0
kPa apresentaram os maiores volumes de drenagem e os menores valores de EC e RCC, indicando perda
de nutrientes no substrato e deficiência nutricional nas plantas. A drenagem foi maior nos tubetes com a
variedade 'Tainung 01' que apresentou menor sistema radicular e também menor condutância estomática
que a 'Sunrise Golden'. Os maiores valores de massa da parte aérea seca e WEU foram obtidos a $6,0 \mathrm{kPa}$
nas mudas da 'Sunrise Golden' ( $0,62 \mathrm{~g}$ e $\left.0,69 \mathrm{~g} \mathrm{~L}^{-1}\right)$ e a $9,0 \mathrm{kPa}$ em 'Tainung 01 ' $(0,35 \mathrm{~g}$ e $0,82 \mathrm{~g}$ L'-1). O
RWC foi menor na regulagem de $9,0 \mathrm{kPa}$ que a $3,0 \mathrm{kPa}$ em ambas as cultivares. Os dados indicam que a
tecnologia de baixo custo para automação da irrigação é promissora. Mesmo assim, novos estudos devem
ser realizados para avaliar sistemas de irrigação de baixa vazão bem como as necessidades nutricionais e
hídricas das diferentes variedades de mamoeiros. Termos para Indexação: Carica papaya L., produção de mudas, automação da irrigação, sensores de umidade.

\footnotetext{
1'(Trabalho 037-13). Recebido em: 04-01-2013. Aceito para publicação em: 19-06-2013.

${ }^{2}$ Eng.Agrônomo Msc. em Fitotecnia pela UFRRJ, Rod. BR 465, km 7 - 23890-000 - Seropédica, RJ - Brasil. E-mail: gu_cod@ hotmail.com

${ }^{3}$ Eng.Agrônomo D.sc., Prof. Associado. Depto. de Ciências Fisiológicas. UFRRJ. E-mail: 1medici@gmail.com

${ }^{4}$ Eng.Agrônomo Dr. Prof. Associado. Depto. de Fitotecnia. UFRRJ. E-mail: marco.vasconcellos@gmail.com

${ }^{5}$ Eng.Agrícola D.sc., Prof. Associado. Depto. de Engenharia. UFRRJ. E-mail: carvalho@ufrrj.br

${ }^{6}$ Eng.Agrônomo D.sc., Prof. Titular. Depto. de Fitotecnia. UFRRJ. E-mail: greenman@amcham.com.br
} 


\section{INTRODUCTION}

Seedling development is crucial step to papaya cropping because it is directly related to early blooming and fruit production in varieties within the Solo and Formosa groups (TRINDADE et al., 2000). Taking into account the main barriers in the papaya supply chain, the production and management of propagative material are important since papaya orchards must be replanted after 3 years (CANESIN and CORREAA, 2006). In addition, papaya trees must be examined for sex determination in the field after flowering (GSCHWEND et al., 2011), increasing the demand for quality seedlings.

Although papaya can be propagated asexually by grafting, cutting or tissue culture, it is commercially produced from seeds, usually sown in different sized polyethylene bags, according to availability and cost (MENDONÇA et al., 2003). Small papaya farmers do not typically produce seedlings in styrofoam trays and plastic tubes because the advantages of these materials have yet to be proven (RUGGIERO, et al.,2011). The use of tubes, however, has increased significantly in specialized mechanized papaya cropping, transferring seedling production to third parties (YAMANISHI et al., 2004).

Irrigation technologies for papaya cropping should prioritize rational management of water resources. Nevertheless, farmers adopt arbitrary irrigation times for different crops, usually based on local practices (SANTOS et al., 2008). In recent years, concerns over the use of irrigation water have increased because insufficient or excess of water may limit crop yield. Efficient irrigation systems are an alternative to more sustainable water use in agriculture, where it is applied for different purposes (CALZADILLA et al., 2010).

A number of automatic irrigation systems can operate with sensors that detect soil, plant or atmosphere variables. Most, however, operate with data acquisition systems and computers (ROMERO et al., 2012). To make this technology available to small farmers, our research team developed a simple, low-cost device for automatic irrigation as an alternative to complex electronic devices. This system operates as a function of water tension in soil and can be constructed by the farmer from home appliance components (MEDICI et al., 2010). In the present study, a miniaturized prototype of this system was evaluated to grow papaya seedlings in tubes.

\section{MATERIAL AND METHODS}

The experiment was carried out under greenhouse conditions in Seropédica, RJ, Brazil $\left(22^{\circ} 45^{\prime} \mathrm{S}\right.$ and $43^{\circ} 41^{\prime} \mathrm{W}, 34-40 \mathrm{~m}$ altitude). Trays containing $280-\mathrm{mL}$ and $190 \mathrm{~mm}$ height round polypropylene tubes were used to produce seedlings. The tubes, containing commercial substrate composed of pinus bark, turf, charcoal and vermiculite, were fertilized with macro and micronutrients (Basaplant BY, Base Agro, Artur Nogueira, BR). The sowing was carried out on September $3^{\text {rd }}, 2011$, with 3 seeds per tube, and seedling emergence observed for 28 days after sowing (DAS). Plants were thinned and only the most vigorous were kept to evaluate growth. These plants were watered manually immediately post sowing and by the automatic irrigation system during 80 days after sowing.

This study was conducted in a randomized block design, consisting of six factorial treatments with five replicates, totaling 30 plots with 18 tubes per plot. A simple $3 \times 2$ factorial arrangement was used, with 3 settings to start irrigation (3.0, 6.0 and $9.0 \mathrm{kPa} \mathrm{STI})$ and 2 papaya varieties: 'Tainung 01' (Formosa group) and 'Sunrise Golden' (Solo group). The irrigation controller is described by Medici et al. (2010). The start setting for the system is determined by the vertical level difference between two of its components, a ceramic capsule (Pozzani Original model - IBAC Ltda., Jundiaí) and a pressure switch (EPR-05 model, Emicol, Itu, Brazil), which were positioned 30,60 and $90 \mathrm{~cm}$ apart, as shown in the Figure 1. The original controller uses a domestic filter candle as a sensor (BATISTA et al., 2013), but in the present study each sensor was handmade from candle materials. They measured 4 x $1 \times 1 \mathrm{~cm}$ and had a longitudinal hole produced with a $5-\mathrm{mm}$ borer. The set up protocol consists of filling the tube with water, and installing the capsule into the substrate. The evapotranspiration reduces soil moisture, and the tension created in the capsule is transmitted by the flexible tube to the pressure switch. The airtight diaphragm of the pressure switch senses the pressure, switching electrical contacts, then activating a hydraulic pump or a solenoid valve of irrigation system. The water supplied moisturizes the substrate and enters the capsule, relieving the tension in the pressure switch, which cuts the current. Therefore, the water potential in the substrate or soil determines the start up and shutdown schedule of the irrigation system. The STI, in absolute values, corresponds to the water column difference between the ceramic capsule 
and the pressure switch. All ceramic capsules were checked to support $20 \mathrm{kPa}$ of water tension without air leaking.

It was used a dripping system with Katif emitters (John Deere Water, Moline, USA). After testing discharge uniformity, these emitters exhibited Christiansen's uniformity coefficient (CU) of nearly $100 \%$ and $4.5 \mathrm{~L} \mathrm{~h}^{-1}$ discharge. To avoid water thread formation, compromising the dripping effect, a plastic tube $(3.5 \mathrm{~cm} \times 0.5 \mathrm{~cm})$ was adapted to each dripper as a drop emitter. The use of drippers allowed watering several plots in a small area, increasing experiment control.

In each factorial treatment, an Alpha mnf hydrometer (FAE Tecnologia, Fortaleza, Brazil) with $0.00001 \mathrm{~m}^{3}$ precision was linked to a monitor and the amount of water applied over the experiment was registered. Each treatment used two independent controllers, totaling 12 controllers during the entire experiment. Each sensor was installed $2.0 \mathrm{~cm}$ below the tube surface, in direct contact with the substrate.

To determine substrate water tension, it was used ceramic capsules, such as those employed in controller sensors, to construct mercury manometer tensiometers. A tensiometer capsule was installed next to each controller sensor. At least 3 daily readings were taken over the experiment, and the 20 highest tensions detected in each treatment were further evaluated.

Initial physicochemical soil analysis showed $1.3 \pm 0.3 \mathrm{mS} \mathrm{cm}^{-1}$ of electrical conductivity (EC), $\mathrm{pH}$ of 5.5 (in water-saturated soil), $0.1 \mathrm{cmol} \mathrm{dm}_{\mathrm{c}}^{-3}$ of $\mathrm{Al}^{+3}, 25.0 \mathrm{cmolc} \mathrm{dm}^{-3}$ of $\mathrm{Ca}^{+2}$ plus $\mathrm{Mg}^{+2}, 17.2$ cmolc $\mathrm{dm}^{3}$ of $\mathrm{Ca}^{+2}, 7.8 \mathrm{~mol} \mathrm{dm}^{-3}$ of $\mathrm{Mg}^{+2}, 48 \%$ of $\mathrm{N}, 164.0$ $\mathrm{mg} \mathrm{dm} \mathrm{m}^{-3}$ of $\mathrm{P}$ and $800 \mathrm{mg} \mathrm{dm}^{-3}$ of $\mathrm{K}^{+}$.

Leaf fertilization was uniformly applied among the treatments at 34, 41, 51 and 56 DAS (days after sowing) by spraying commercial leaf fertilizer containing $0.2 \mathrm{~g} \mathrm{~L}^{-1} \mathrm{~N}$.

Relative air humidity and temperature were monitored in the greenhouse with a thermohygrometer Data Logger (Impac IP-747RH model, São Paulo, BR), configured to store mean values every hour.

The effects of irrigation levels on germination and emergency velocity index (EVI) under greenhouse conditions were evaluated using 5 subsamples of 54 seeds sown in the tubes. The germination test was carried out at 28 DAS and then, the percentages of emerged seedlings were calculated. For EVI determination, seedlings with completely opened cotyledons were counted daily from sowing to $28 \mathrm{DAS}$. EVI calculation was based on the germination test, adapting Maguire's (1962) equation (Eq.1):

$\mathrm{EVI}=\mathrm{E} 1 / \mathrm{N} 1+\mathrm{E} 2 / \mathrm{N} 2+\ldots+\mathrm{En} / \mathrm{Nn}$,

Where: E1, E2 ... En correspond to the number of seeds emerged, and N1, N2 ... Nn to the number of days after the start of the test.

After 65 DAS, the plants were separated into shoots and roots, which were dried to constant weight in a forced air oven at $60^{\circ} \mathrm{C}$ and weighed on an analytical scale.

Plant growth was assessed by height $(\mathrm{cm})$, measured at 65 DAS, from the stem area to the terminal bud, using a millimeter ruler. Chlorophyll content (SPAD unit) was estimated in the $4^{\text {th }}$ or $5^{\text {th }}$ leaf (from the growing tip) with a portable Minolta SPAD-502 chlorophyll meter (Ramsay, New Jersey, EUA). Two measures were taken from the adaxial leaf surface of 5 plants from each plot, at 51 and 62 DAS. Stomatal conductance (gs) and photosynthetic photon flux density (PPFD) were measured with an AP4 porometer (Delta T Company, England) on the abaxial leaf surface of the $4^{\text {th }}$ or $5^{\text {th }}$ leaf (from the growing tip). This measure was taken at $61 \mathrm{DAS}$, at 09:00 am, 12:00 pm and 03:00 pm, the water vapor pressure deficit (VPD) was calculated following equation described by (REIS et al., 2008). Leaf area $\left(\mathrm{cm}^{2}\right)$ was measured at 79 DAS in leaves detached from 4 plants in each plot and analyzed using SIARCS software (version 3.0, EMBRAPA) described by (MARTINS et al., 2007).

Relative water content (RWC) was analyzed at 79 DAS at 12:00 pm. Leaves were collected in the field, properly stored in plastic bags and cooled to avoid tissue dehydration until analyzed in the laboratory. The measuring method was adapted from protocol described by Cia et al. (2012), using the following equation (Eq.2):

$$
\mathrm{RWC}=(\mathrm{FW}-\mathrm{DW}) /(\mathrm{TW}-\mathrm{DW}) \times 100
$$

Where: FW is fresh weight, DW dry weight and TW turgid weight.

To obtain FW, 10 leaf disks of known area $\left(1.0 \mathrm{~cm}^{2}\right)$ were removed from the $3^{\text {rd }}$ or $4^{\text {th }}$ leaves, fully expanded and immersed in water for $12 \mathrm{~h}$ for subsequent TW determination. To that end, the disks were dried in a forced air oven at $60^{\circ} \mathrm{C}$ until constant weight. Leaf weights were measured on an analytical scale.

Soil EC at a tube depth of $10 \mathrm{~cm}$ was evaluated at 62 DAS using a portable HI 98331 Soil Tester (Hanna Instruments, Woonsocket, USA). 
Tube drainage was assessed using 4 randomly chosen collectors in each plot, at 3 different phases of the experiment. Each collector was adapted to a tube and drainage was measured with a graduated cylinder after irrigation events. The phases evaluated were 1-3, 20-33 and 46-68 DAS, in order to observe drainage in the 6 treatments.

At 65 DAS, dry mass values for the entire plant and water content applied throughout this period were used to calculate water use efficiency (WUE), which corresponds to the ratio of plant dry mass in the tube $(\mathrm{g})$ to the amount of water applied (L).

A completely randomized experiment with 3 controller settings was carried out to test the time to shutdown response of the automatic controller under laboratory conditions. To that end, a capsule was dried in paper towel to start the controller, and the time to shutdown was recorded after the half capsule was immersed into water.

The results were analyzed using the F test, and statistically different means were compared using the LSD test at a significance level of 0.05 . Germination data, determined as percentage, were arcsine transformed $(\mathrm{x} / 100)$ and EVI data was transformed using the square root of $(x+0.5)$.

\section{RESULTS AND DISCUSSION}

In the greenhouse environment, mean air temperature was $23.7 \pm 4.8^{\circ} \mathrm{C}$ and relative air humidity $69.7 \pm 17.4 \%$ up to 80 DAS. The temperature recorded (around $25^{\circ} \mathrm{C}$ ) is close to the ideal level for papaya seedlings development (SERRANO and CATTANEO, 2010).

As expected, maximum soil water tension varied according to the different controller settings (Table 1) and, as observed by Medici et al. (2010), the values measured by tensiometer were slight higher than the controller settings. The controller capsule was likely more susceptible to moisturizing than more distant areas, such as where the tensiometer capsule was installed.

The seeds of the two varieties tested exhibited similar germination percentage under the different controller settings (Table 2) and the 'Tainung 01' variety had lower EVI. The tensions adopted in the present study were not expected to compromise germination, since Aroucha et al. (2006) found that papaya seed germination decreased only above 100Kpa.

Drainage was higher under $3.0 \mathrm{kPa}$ conditions, mainly for the 'Tainung 01 ' variety (Table 3 ). This result is partially explained by the longer shutdown time required by the controller operating at $3.0 \mathrm{kPa}$ STI (26 s versus $9 \mathrm{~s}$ and $5 \mathrm{~s}$ at 6.0 and $9.0 \mathrm{kPa}$ STI, respectively). Additionally, the poor root system of 'Tainung 01' (Table 4) contributed to the increase in drainage from its tubes, given their lower resistance to water percolation. Over the experiment, drainage increased in the treatment with 'Tainung 01' and $3.0 \mathrm{kPa} \mathrm{STI}$, and the dark colored water drained in this treatment indicates soil losses. The use of low discharge emitters applying the low-cost irrigation system for dripping or micro-sprinkling might minimize excess drainage in the tubes.

Exhibiting the same pattern of water use efficiency (WUE), 'Sunrise Golden' and 'Tainung 01 ' growths were higher at $6.0 \mathrm{kPa}$ and $9.0 \mathrm{kPa}$ of STI, respectively (Table 4). The lowest seedling growth obtained at $3.0 \mathrm{kPa}$ in these two cultivars was probably related to high drainage, which may have diminished soil nutrient content, as indicated by EC values (Table 3). Accordingly, the low chlorophyll levels obtained with $3.0 \mathrm{kPa}$ of STI (Table 4) could be related to the low nutrient availability in this treatment.

The maximum seedling growth was achieved with the highest shoot dry mass of $0.62 \mathrm{~g}$ observed at 65 DAS (Table 4). It was at an intermediate level compared to other studies. Costa et al. (2011) found $1.89 \mathrm{~g}$ shoots of dry mass for papaya seedlings grown in $1.5 \mathrm{~L}$ pots at $50 \mathrm{DAS}$. Yamanishi et al. (2004) found seedlings weighing $0.18 \mathrm{~g}$ grown in $0.05 \mathrm{~L}$ pots at $45 \mathrm{DAS}$. In the present study, a limiting factor in seedling growth was nitrogen deficiency, as indicated by the decrease in chlorophyll levels from 51 to 62 DAS, it was observed in all the treatments except 'Tainung 01' at $9.0 \mathrm{kPa}$ STI. Castro et al. (2011) reported that values under 20 SPAD units indicate senescence in papaya seedlings.

The highest mean height observed at 65 DAS was $16.9 \mathrm{~cm}$ (Table 4), which is close to the values reported in other studies at 60 DAS: $7.75 \mathrm{~cm}$ in 70 $\mathrm{mL}$ pots, $19 \mathrm{~cm}$ in $750 \mathrm{~mL}$ pots (MENDONÇA et al., 2003), $16 \mathrm{~cm}$ in $673 \mathrm{~mL}$ pots (KUSDRA et al., 2008) and $8.06 \mathrm{~cm}$ in $600 \mathrm{~mL}$ pots (HAFLE et. al., 2009).

The RWC of $90.0 \%$ in plants grown at $9.0 \mathrm{kPa}$ of STI indicates that this condition had lower water availability than that grown at $3.0 \mathrm{kPa}$, which had $94.4 \%$ of RWC (Table 4 ). Nevertheless, plants with $90 \%$ of RWC are not considered to be under severe drought, given that Mahouachi et al. (2012) reported RWC values between 89 and $93 \%$ in adequately watered papaya seedlings.

The 'Sunrise Golden' variety had higher stomatal conductance than 'Tainung 01' (Table 5). 
This result may be related to the higher growth of 'Sunrise Golden' seedlings and smaller root system of 'Tainung 01'. The stomatal conductance values recorded were close to those reported by Mahouachi et al. (2012), and the increase from 09:00 am to $12: 00 \mathrm{pm}$, observed in all factorial treatments, may be associated to the higher PPFD at midday (Table 5). On the other hand, stomatal conductance decreased from 12:00 pm to $03: 00 \mathrm{pm}$ in most treatments, probably due to the decrease in PPFD and increase in vapor pressure deficit (VPD). According to Machado Filho et al. (2006), an increase in VPD is the primary factor leading to stomatal closure in papaya genotypes.

For controller settings at 3.0,6.0 and $9.0 \mathrm{kPa}$ of STI, water use efficiencies in the 'Sunrise Golden' variety were $0.21,0.69$ and $0.58 \mathrm{~g} \mathrm{~L}^{-1}$ and in 'Tainung 01 ' were $0.03,0.18$ and $0.82 \mathrm{~g} \mathrm{~L}^{-1}$, respectively. The highest WUE levels $\left(0.69\right.$ and $\left.0.82 \mathrm{~g} \mathrm{~L}^{-1}\right)$ observed in conditions of poor drainage, are far compared to those obtained in Festuca arundinacea $\left(1-2 \mathrm{~g} \mathrm{~L}^{-1}\right)$ (GULÍAS et al., 2012) and in tomato crop (2.5-3.5 g $\left.\mathrm{L}^{-1}\right)$ (REINA-SÁNCHEZ et al., 2005), but are close to those obtained for lettuce crop $\left(0.37-0.78 \mathrm{~g} \mathrm{~L}^{-1}\right)$ (EL-SHINAWY et al., 1996).

Taken together, the results indicate that the low-cost irrigation controller can be used in papaya seedling production. However, further studies should be carried out to test emitters of lower discharge in order to reduce drainage, adjust fertilization, and calibrate the controller to seedlings of different papaya varieties.

TABLE 1- Maximum water tension in substrate of two cultivars of papaya seedlings automatically watered under three substrate water tensions for starting irrigation (STI).

\begin{tabular}{cccccc}
\hline \multirow{2}{*}{ Variable } & \multirow{2}{*}{ Cultivars } & \multicolumn{3}{c}{ STI (kPa) } & \multirow{2}{*}{ Mean } \\
\cline { 3 - 5 } & & $\mathbf{3 . 0}$ & $\mathbf{6 . 0}$ & $\mathbf{9 . 0}$ & \\
\hline Maximum & Sunrise Golden & 4.8 & 7.8 & 11.5 & $8.0 \mathrm{~A}$ \\
tension & Tainung 01 & 5.1 & 7.1 & 12.4 & $8.2 \mathrm{~A}$ \\
$(\mathrm{kPa})$ & Mean & $5.0 \mathrm{c}$ & $7.5 \mathrm{~b}$ & $12.0 \mathrm{a}$ & \\
$\mathrm{n}=20$ & $\mathrm{CV} \%$ & & 20.8 & & \\
\hline
\end{tabular}

Averages within a column followed by the same upper case letter do not differ significantly $(\mathrm{P}<0.05)$, according to F-test. Averages within a row followed by the same lower case letter do not differ significantly $(\mathrm{P}<0.05)$, according to LSD test.

TABLE 2. Percentage of germination and emergence velocity index (EVI) in seeds of two cultivars of papaya automatically watered under three substrate water tensions for starting irrigation (STI).

\begin{tabular}{|c|c|c|c|c|c|}
\hline \multirow{2}{*}{ Variables } & \multirow{2}{*}{ Cultivars } & \multicolumn{3}{|c|}{ STI (kPa) } & \multirow{2}{*}{ Mean } \\
\hline & & 3.0 & 6.0 & 9.0 & \\
\hline \multirow{4}{*}{$\begin{array}{c}\text { Percentage } \\
\text { of germination } \\
(\%)\end{array}$} & Sunrise Golden & 72.96 & 69.63 & 66.67 & $69.75 \mathrm{~A}$ \\
\hline & Tainung 01 & 67.78 & 62.96 & 68.89 & $66.54 \mathrm{~A}$ \\
\hline & Mean & $70.37 \mathrm{a}$ & $66.29 \mathrm{a}$ & $67.78 \mathrm{a}$ & \\
\hline & $\mathrm{CV} \%$ & & 11.45 & & \\
\hline \multirow{4}{*}{ EVI } & Sunrise Golden & 2.40 & 2.27 & 2.15 & $2.27 \mathrm{~A}$ \\
\hline & Tainung 01 & 2.19 & 1.93 & 2.07 & $2.06 \mathrm{~B}$ \\
\hline & Mean & $2,23 \mathrm{a}$ & $2,10 \mathrm{a}$ & $2,11 \mathrm{a}$ & \\
\hline & $\mathrm{CV} \%$ & & 3,95 & & \\
\hline
\end{tabular}

Averages within a column followed by the same upper case letter do not differ significantly $(\mathrm{P}<0.05)$, according to F-test. Averages within a row followed by the same lower case letter do not differ significantly $(\mathrm{P}<0.05)$, according to LSD test. 
TABLE 3- Drainage and electrical conductivity (EC) in substrate of two cultivars of papaya automatically watered under three substrate water tensions for starting irrigation (STI).

\begin{tabular}{|c|c|c|c|c|c|}
\hline \multirow{2}{*}{ Variables } & \multirow{2}{*}{ Cultivars } & \multicolumn{3}{|c|}{ STI (kPa) } & \multirow{2}{*}{ Mean } \\
\hline & & 3.0 & 6.0 & 9.0 & \\
\hline Drainage & Sunrise Golden & $54.2 \mathrm{Ba}$ & $20.6 \mathrm{Bb}$ & $33.2 \mathrm{Ab}$ & 36.0 \\
\hline 1-3 DAS & Tainung 01 & $69.2 \mathrm{Aa}$ & $40.0 \mathrm{Ab}$ & $29.4 \mathrm{Ac}$ & 46.2 \\
\hline$\left(\mathrm{mL}\right.$ tube $\left.{ }^{-1}\right)$ & Mean & 61.7 & 30.3 & 31.3 & \\
\hline $\mathrm{n}=4$ & $\mathrm{CV} \%$ & & 24.06 & & \\
\hline Drainage & Sunrise Golden & $32.2 \mathrm{Ba}$ & $27.8 \mathrm{Ba}$ & $22.8 \mathrm{Aa}$ & 27.6 \\
\hline 20-33 DAS & Tainung 01 & $140.6 \mathrm{Aa}$ & $124.8 \mathrm{Ab}$ & $12.4 \mathrm{Bc}$ & 92.6 \\
\hline$\left(\mathrm{mL}\right.$ tube $\left.{ }^{-1}\right)$ & Mean & 86.4 & 76.3 & 17.6 & \\
\hline $\mathrm{n}=4$ & $\mathrm{CV} \%$ & & 15.88 & & \\
\hline Drainage & Sunrise Golden & $67.0 \mathrm{Ba}$ & $24.8 \mathrm{Bb}$ & $25.6 \mathrm{Bb}$ & 39.1 \\
\hline 46-68 DAS & Tainung 01 & $162.0 \mathrm{Aa}$ & $125.8 \mathrm{Ab}$ & $71.2 \mathrm{Ac}$ & 119.7 \\
\hline$\left(\mathrm{mL}\right.$ tube $\left.^{-1}\right)$ & Mean & 114.5 & 75.3 & 48.4 & \\
\hline$n=4$ & $\mathrm{CV} \%$ & & 13.69 & & \\
\hline \multirow{4}{*}{$\begin{array}{c}\mathrm{EC} \\
\left(\mathrm{mS} \mathrm{cm}^{-1}\right) \\
\mathrm{n}=3\end{array}$} & Sunrise Golden & 0.08 & 0.14 & 0.10 & $0.10 \mathrm{~A}$ \\
\hline & Tainung 01 & 0.05 & 0.08 & 0.06 & $0.06 \mathrm{~B}$ \\
\hline & Mean & $0.06 b$ & $0.11 \mathrm{a}$ & $0.08 \mathrm{~b}$ & \\
\hline & $\mathrm{CV} \%$ & & 33.12 & & \\
\hline
\end{tabular}

Averages within a column followed by the same upper case letter do not differ significantly $(\mathrm{P}<0.05)$, according to F-test. Averages within a row followed by the same lower case letter do not differ significantly $(\mathrm{P}<0.05)$, according to LSD test.

TABLE 4 - Growth traits, relative water content and relative chlorophyll content in seedlings of two cultivars of papaya automatically watered under three substrate water tensions for starting irrigation (STI)

\begin{tabular}{|c|c|c|c|c|c|}
\hline \multirow{2}{*}{ Variables } & \multirow{2}{*}{ Cultivars } & \multicolumn{3}{|c|}{ STI (kPa) } & \multirow{2}{*}{ Mean } \\
\hline & & 3.0 & 6.0 & 9.0 & \\
\hline \multirow{4}{*}{$\begin{array}{l}\text { Leaf area } \\
\qquad\left(\mathrm{cm}^{2}\right) \\
\quad n=4\end{array}$} & Sunrise Golden & $32.54 \mathrm{Ab}$ & $69.06 \mathrm{Aa}$ & $68.16 \mathrm{Aa}$ & 56.59 \\
\hline & Tainung 01 & $22.19 \mathrm{Ab}$ & $35.04 \mathrm{Bb}$ & $57.33 \mathrm{Aa}$ & 38.18 \\
\hline & Mean & 27.36 & 52.05 & 62.74 & \\
\hline & $\mathrm{CV} \%$ & & 21.71 & & \\
\hline \multirow{4}{*}{$\begin{array}{l}\text { Plant height } \\
\qquad(\mathrm{cm}) \\
\mathrm{n}=4\end{array}$} & Sunrise Golden & 12.3 & 16.9 & 15.5 & $14.9 \mathrm{~A}$ \\
\hline & Tainung 01 & 9.4 & 11.6 & 11.2 & $10.7 \mathrm{~B}$ \\
\hline & Mean & $10.9 b$ & $14.2 \mathrm{a}$ & $13.4 \mathrm{a}$ & \\
\hline & $\mathrm{CV} \%$ & & 13.44 & & \\
\hline \multirow{3}{*}{$\begin{array}{l}\text { Shoot dry } \\
\text { weigth } \\
\text { (g) }\end{array}$} & Sunrise Golden & $0.27 \mathrm{Ac}$ & $0.62 \mathrm{Aa}$ & $0.43 \mathrm{Ab}$ & 0.44 \\
\hline & Tainung 01 & $0.11 \mathrm{Bb}$ & $0.23 \mathrm{Bab}$ & $0.35 \mathrm{Aa}$ & 0.23 \\
\hline & Mean & 0.19 & 0.43 & 0.39 & \\
\hline \multirow{2}{*}{$\frac{n \geq 5}{\text { Root dry }}$} & $\mathrm{CV} \%$ & & 26.73 & & \\
\hline & Sunrise Golden & $0.16 \mathrm{Ab}$ & $0.29 \mathrm{Aa}$ & $0.23 \mathrm{Ab}$ & 0.23 \\
\hline & Tainung 01 & $0.06 \mathrm{Ba}$ & $0.10 \mathrm{Ba}$ & $0.10 \mathrm{Ba}$ & 0.09 \\
\hline $\begin{array}{l}\text { weigth } \\
(\mathrm{g})\end{array}$ & Mean & 0.11 & 0.20 & 0.17 & \\
\hline$n \geq 5$ & $\mathrm{CV} \%$ & & 22.16 & & \\
\hline \multirow{4}{*}{$\begin{array}{c}\text { Relative } \\
\text { water content } \\
n=10\end{array}$} & Sunrise Golden & 96.60 & 93.20 & 94.40 & $94.73 \mathrm{~A}$ \\
\hline & Tainung 01 & 95.80 & 95.40 & 90.00 & $93.73 \mathrm{~A}$ \\
\hline & Mean & $96.20 \mathrm{a}$ & $94.30 \mathrm{ab}$ & $92.20 \mathrm{~b}$ & \\
\hline & $\mathrm{CV} \%$ & & 3.17 & & \\
\hline \multirow{4}{*}{$\begin{array}{c}\text { Relative chlorophyll content (51 DAS) } \\
\text { SPAD Units } \\
\mathrm{n}=10\end{array}$} & Sunrise Golden & $26.76 \mathrm{Aa}$ & $35.50 \mathrm{Aa}$ & $34.92 \mathrm{Ba}$ & 32.39 \\
\hline & Tainung 01 & $20.00 \mathrm{Bc}$ & $27.44 \mathrm{Bb}$ & $42.86 \mathrm{Aa}$ & 30.10 \\
\hline & Mean & 23.38 & 37.47 & 34.92 & \\
\hline & $\mathrm{CV} \%$ & & 14.57 & & \\
\hline \multirow{4}{*}{$\begin{array}{l}\text { Relative chlorophyll content (62 DAS) } \\
\text { SPAD Units } \\
n=10\end{array}$} & Sunrise Golden & $18.34 \mathrm{Ab}$ & $25.54 \mathrm{Aa}$ & $27.70 \mathrm{Ba}$ & 24.85 \\
\hline & Tainung 01 & $9.84 \mathrm{Bc}$ & $19.36 \mathrm{Bb}$ & $45.34 \mathrm{Aa}$ & 23.86 \\
\hline & Mean & 14.09 & 22.45 & 36.52 & \\
\hline & CV\% & & 18. & & \\
\hline
\end{tabular}

Averages within a column followed by the same upper case letter do not differ significantly $(\mathrm{P}<0.05)$, according to F-test. Averages within a row followed by the same lower case letter do not differ significantly $(\mathrm{P}<0.05)$, according to LSD test. 
TABLE 5- Stomatal conductance $\left(\mathrm{mmol} \mathrm{m}^{-2} \mathrm{~s}^{-1}\right)$ in seedlings of two cultivars of papaya automatically watered under three substrate water tensions for starting irrigation (STI).

\begin{tabular}{|c|c|c|c|c|c|c|c|}
\hline \multirow{2}{*}{ Schedule } & \multirow{2}{*}{ 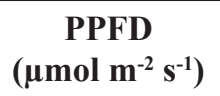 } & \multirow{2}{*}{$\begin{array}{l}\text { VPD } \\
(\mathrm{kPa})\end{array}$} & \multirow{2}{*}{ Cultivars } & \multicolumn{3}{|c|}{ STI (kPa) } & \multirow{2}{*}{ Mean } \\
\hline & & & & 3.0 & 6.0 & 9.0 & \\
\hline \multirow{3}{*}{ 09:00 am } & \multirow{3}{*}{418.9} & \multirow{3}{*}{1.146} & Sunrise Golden & 96.6 & 129.8 & 114.6 & $113.7 \mathrm{~A}$ \\
\hline & & & Tainung 01 & 75.5 & 59.6 & 37.3 & $57.5 \mathrm{~B}$ \\
\hline & & & Mean & $86.1 \mathrm{a}$ & $94.7 \mathrm{a}$ & $75.9 \mathrm{a}$ & \\
\hline \multirow{3}{*}{$12: 00 \mathrm{pm}$} & \multirow{3}{*}{517.3} & \multirow{3}{*}{2.093} & Sunrise Golden & 135.6 & 182.0 & 182.8 & $166.8 \mathrm{~A}$ \\
\hline & & & Tainung 01 & 86.3 & 143.4 & 43.0 & $90.9 \mathrm{~B}$ \\
\hline & & & Mean & $111.0 \mathrm{a}$ & $162.7 \mathrm{a}$ & $112.9 \mathrm{a}$ & \\
\hline \multirow{3}{*}{ 03:00 pm } & \multirow{3}{*}{432.9} & \multirow{3}{*}{2.762} & Sunrise Golden & 97.2 & 128.2 & 106.0 & $110.5 \mathrm{~A}$ \\
\hline & & & Tainung 01 & 78.6 & 113.0 & 61.7 & $84.4 \mathrm{~A}$ \\
\hline & & & Mean & $87.9 \mathrm{a}$ & $120.6 \mathrm{a}$ & $83.9 \mathrm{a}$ & \\
\hline
\end{tabular}

Averages within a column followed by the same upper case letters do not differ significantly $(\mathrm{P}<0.05)$, according to F-test. Averages within a row followed by the same lower case letter do not differ significantly $(\mathrm{P}<0.05)$, according to LSD test.

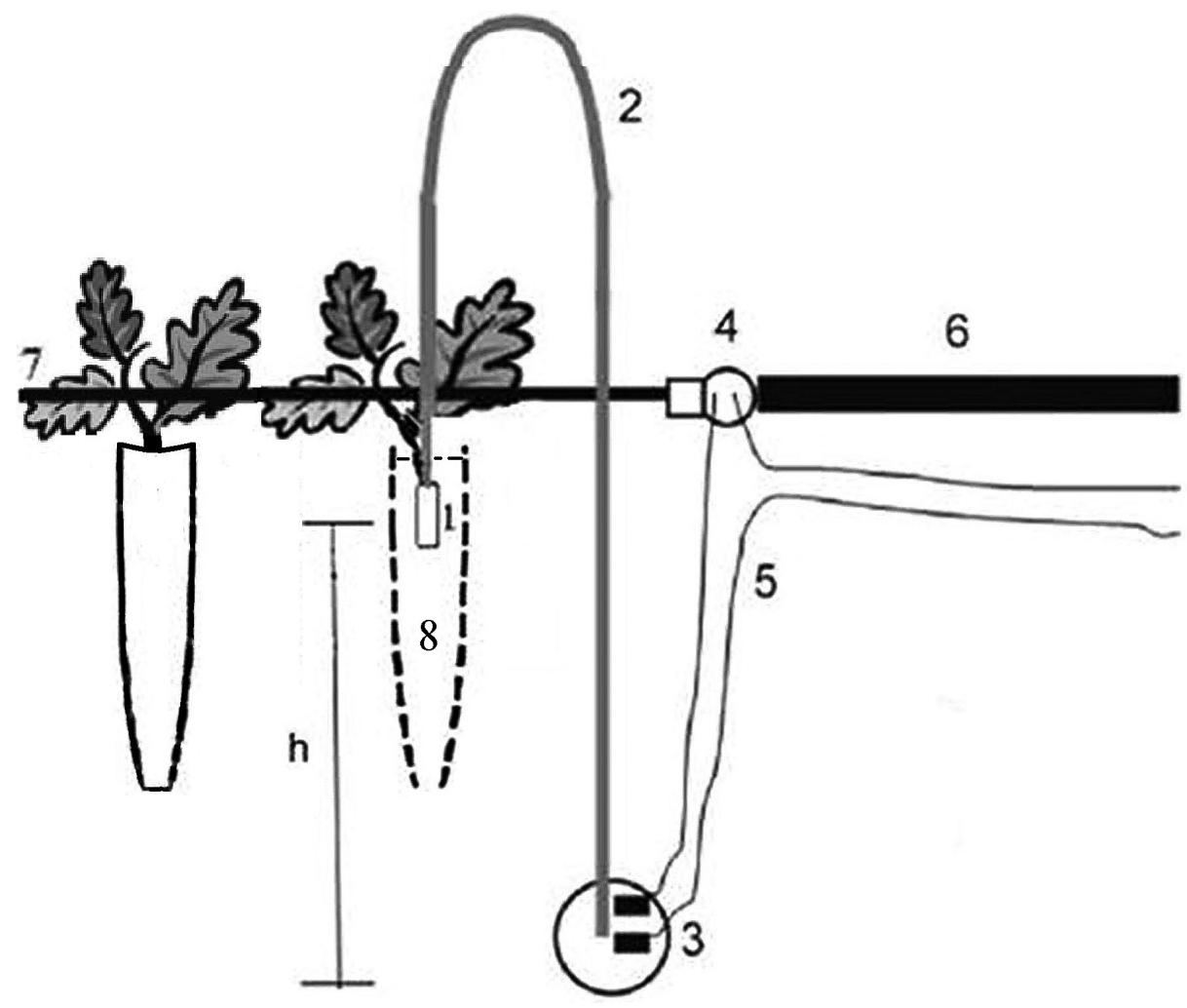

FIGURE 1 - Set up and operation of the irrigation controller. Source: adapted from Medici et al. (2010). 1 - ceramic capsule; 2 - flexible tube; 3 - pressure switch; 4 - solenoid valve; 5 - electrical wires; 6 - water pipe: 7 - irrigation system; 8 - plant substrate. "h"- controller adjustment. 


\section{CONCLUSION}

Seed germination was similar under the three different settings for starting the automatic irrigation controller.

At 3.0 and $6.0 \mathrm{kPa}$ STI, the 'Tainung 01' variety exhibited a smaller root system and a higher drainage than the 'Sunrise Golden' variety.

The best seedling growth and water use efficiency were obtained with a controller setting of $6.0 \mathrm{kPa}$ STI for 'Sunrise Golden' and $9.0 \mathrm{kPa}$ STI for the 'Tainung 01 ' varieties.

\section{ACKNOWLEDGEMENTS}

To CPGF - UFRRJ program; to CAPES/ REUNI - UFRRJ and CAPES (AUXPE-PNPD 02779/09) for the financial support provided.

\section{REFERENCES}

AROUCHA, E.M.M.; SILVA, R.F.; NUNES, G.H. S.; AROUCHA, M.C.M.; VIANA, A.P. Osmotic conditioning in the papaya seeds germination. Revista Caatinga, Mossoró, v.19, n.3, p.272-277, 2006.

BATISTA, S.C.O.; CARVALHO, D.F.; ROCHA, H.S.; SANTOS, H.T.; MEDICI, L.O. Production of automatically watered lettuce with a low cost controller. Journal of Food, Agriculture and Environment, Helsinki, v.11, n.22, p. 485-489, 2013.

CALZADILLA, A.; REHDANZ, K.; TOL, R.S.J. The economic impact of more sustainable water use in agriculture: A computable general equilibrium analysis. Journal of Hydrology, Amsterdam, v.384, p.292-305, 2010.

CANESIN, R. C. F. S.; CORRÊA, L. de S. Uso de esterco associado à adubação mineral na produção de mudas de mamoeiro (Carica papaya L.). Revista Brasileira de Fruticultura, Jaboticabal, v. 28, n. 3, p. 481-486, 2006.

CASTRO, F.A.; CAMPOSTRINI, E.; TORRES NETTO, A.; VIANA, L. H. Relationship between photochemical efficiency (JIP-Test Parameters) and portable chlorophyll meter readings in papaya plants. Brazilian Journal of Plant Physiology, Londrina, v.23, n.4, p.295-304, 2011.
CIA, M. C.; GUIMARAES, A. C. R.; MEDICI, L. O.; CHABREGAS, S. M.; AZEVEDO, R. A. Antioxidant responses to water deficit by drought-tolerant and -sensitive sugarcane varieties. Annals of Applied Biology, Warwick, v. 161, n.3, p.313-324, 2012.

EL-SHINAWY, M.Z.; MEDANY, M.A.; ABOUHADID, A.F.; SOLIMAN, E.M.; EL-BELTAGY, A.S. Comparative water use efficiencies of lettuce plants grown in different production systems. Acta Horticulturae, Wageningen, v. 434, p.53-58, 1996.

GSCHWEND, A.R.; YU, Q.; MOORE, P.; SASKI, C.; CHEN, C; WANG, J.; NA, J. K.; MING, R. Construction of papaya male and female BAC libraries and application in physical mapping of the sex chromosomes. Journal of Biomedicine and Biotechnology, New York, v. 2011, p. 7, 2011.

GULIAS, J.; SEDDAIU, G.; CIFRE, J.; SALIS, M.; LEDDA, L. Leaf and plant water use efficiency in cocksfoot and tall fescue accessions under differing soil water availability. Crop Science, Madison, v.52, p.2321-2331, 2012.

HAFLE, O. M.; SANTOS, V. A. dos; RAMOS, J. D.; CRUZ, M. C. M.; MELO, P. C. Production of seedlings of papaya tree using bokashi and lithothamnium. Revista Brasileira de Fruticultura, Jaboticabal, v.31, n.1, p.245-251, 2009.

KUSDRA, J. F.; MOREIRA, D. F. SILVA, S. S.; ARAÚJO NETO, S. E.; SILVA, R. G. Use of earthworm casting in the production of papaya seedlings. Revista Brasileira de Fruticultura, Jaboticabal, v.30, n.2, p.492-497, 2008.

MACHADO FILHO, J. A.; CAMPOSTRINI, E.; YAMANISHI, O. K.; FAGUNDES, G. R. Seasonal variation of leaf gas exchange in papaya plants grown under field condition. Bragantia, Campinas, v.65, n.2, p.185-196, 2006.

MAHOUACHI, J.; ARGAMASILLA, R.; GÓMEZCADENAS, A. Influence of exogenous glycine betaine and abscisic acid on papaya in responses to water-deficit stress. Journal of Plant Growth Regulation, New York, v.31, p.1-10, 2012.

MAGUIRE, J.D. Speed of germination aid in selection and evaluation for seedling emergence and vigor. Crop Science, Madison, v.2, n.2, p.176-177, 1962. 
MARTINS, C.A.da C.; PORTZ, A.; BRASIL, F. da C.; SILVA, E. M.R. da; LIMA, E.; ZONTA, E. Pré-enraizamento de mudas de mandioquinhasalsa em diferentes bandejas e substratos com fungos micorrízicos arbusculares. Ciência e Agrotecnologia, Lavras, v.31, n.1, p.106-112, 2007.

MEDICI, L. O.; ROCHA, H. S. da; CARVALHO, D. F. de; PIMENTEL, C.; AZEVEDO, R. A. Automatic controller to water plants. Scientia Agricola, Piracicaba, v.67, n.6, p.727-730, 2010.

MENDONÇA, V.; NETO, S.; RAMOS, J.; PIO, R.; GONTIJO, T. Different substrates and recipients in the formation of papaya seedlings 'Sunrise Solo'. Revista Brasileira de Fruticultura, Jaboticabal, v.25, n.1, p.127-130, 2003.

REINA-SÁNCHEZ, A.; ROMERO-ARANDA, R.; CUARTERO, J. Plant water uptake and water use efficiency of greenhouse tomato cultivars irrigated with saline water. Agricultural Water Management, Amsterdam, v.78, p.54-66, 2005.

REIS, F. de O.; CAMPOSTRINI, E.; TORRES NETTO, A. Mancha fisiológica do mamão 'Formosa': relações com o potencial hídrico do solo, o teor de sólidos solúveis totais do látex e as variáveis do clima. Ciência e Agrotecnologia, Lavras, v. 32, n. 5,2008 .
ROMERO, R; MURIEL, J.L.; GARCÍA, I.; MUÑOZ DE LA PEÑA D. Research on automatic irrigation control: State of the art and recent results. Agricultural Water Management, Amsterdam, v.114, p.59-66, 2012.

RUGGIERO, C.; MARIN, S. L. D.; DURIGAN, J. F. Revista Brasileira de Fruticultura, Jaboticabal, v. 33, n.1 - edição especial, p. 76 - 91, 2011.

SANTOS, F. S. S. dos; VIANA, T. V. A.; AZEVEDO B. M. de; OLIVEIRA, C. W.; SOUSA, A. E.C. Effect of different depth irrigation in papaya crop. Engenharia Agrícola, Jaboticabal, v.28, n.4, p.673$680,2008$.

SERRANO, L. A. L.; CATTANEO, L. F. O cultivo do mamoeiro no Brasil. Revista Brasileira de Fruticultura, Jaboticabal, v.32, n.3, p.657-959, 2010.

TRINDADE, A.V.; FARIA, N.G.; ALMEIDA, F.P. Use of manure for development of papaya seedlings colonized with mycorrhizal fungi. Pesquisa Agropecuária Brasileira, Brasília, v.35, n.7, 2000.

YAMANISHI, O. K.; FAGUNDES, G. R.; FILHO, J. A. M.; FILHO, G. V. de. Different growth medium and fertilizer effects on papaya seedlings growth. Revista Brasileira de Fruticultura, Jaboticabal, v.26, n.2, p.276-279, 2004. 